\title{
Vegetative propagation of Plukenetia polyadenia by cuttings: effects of leaf area and indole-3-butyric acid concentration
}

\author{
R. Solis ${ }^{a *}$, M. Pezo ${ }^{a}$, G. Diaz ${ }^{a}$, L. Arévalo and D. Cachique \\ aPrograma de Investigación en Manejo Integral del Bosque y Servicios Ambientales - PROBOSQUES, Instituto de \\ Investigaciones de la Amazonía Peruana, Jr. Belén Torres de Tello 135 - Morales, San Martín, Perú \\ *e-mail: rsolis@iiap.org.pe
}

Received: December 4, 2015 - Accepted: April 27, 2016 - Distributed: August 31, 2017

(With 1 figure)

\begin{abstract}
The seeds of Plukenetia polyadenia have high levels of unsaturated fatty acids and are used as medicine and food for native people in the Peruvian and Brazilian Amazon. The objective of this study was to develop a method for vegetative propagation of Plukenetia polyadenia by rooting of cuttings. The experiment was laid out in a randomized complete block design with 12 treatments and 3 replications of 8 cuttings, in a $3 \times 4$ factorial arrangement. The factors were: 3 levels of leaf area (25, 50 and 75\%) and 3 indole-3-butyric acid - IBA concentrations $(9.84,19.68$ and 29.52mM) and a control without IBA. Data were submitted to analysis of variance and means were compared by Tukey test at $5 \%$ probability. Our results show that the use of cuttings with $50 \%$ of leaf area and treatment with $29.52 \mathrm{mM}$ of IBA induced high percentages of rooting $(93 \%)$ and the best root formation. Vegetative propagation of Plukenetia polyadenia by cuttings will be used as a tool to conserve and propagate germplasm in breeding programs.
\end{abstract}

Keywords: Plukenetia polyadenia, rooting, leaf area, IBA.

\section{Propagação vegetativa de Plukenetia polyadenia por estacas: efeitos de área foliar e concentração de ácido indol-3-butírico}

\begin{abstract}
Resumo
As sementes de Plukenetia polyadenia têm altos níveis de ácidos graxos insaturados e são utilizadas como medicamentos e alimentos para as pessoas nativas da Amazônia Peruana e Brasileira. O objetivo do trabalho foi desenvolver um método de propagação vegetativa de Plukenetia polyadenia por meio do enraizamento de estacas em câmeras de sub-irrigação. Foi utilizado um delineamento de blocos ao acaso com 12 tratamentos e 3 repetições de 8 estacas, e esquema fatorial $3 \times 4$. Os fatores foram: 3 níveis de área foliar (25, 50 e 75\%) e 3 doses de ácido indol-3-butírico - AIB (9,84; 19,68 e $29,52 \mathrm{mM}$ ) e um controle sem AIB. Os dados foram submetidos à análise de variância e as médias foram comparadas pelo teste de Tukey a $5 \%$ de probabilidade. A maior taxa de enraizamento de estacas (93\%) foi obtida com $29,52 \mathrm{mM}$ de AIB como indutor hormonal e estacas com área foliar de 50\%. A propagação vegetativa de Plukenetia polyadenia por estacas será usada como ferramenta para conservar e propagar germoplasma em programas de melhoramento.
\end{abstract}

Palavras-chave: Plukenetia polyadenia, enraizamento, área foliar, AIB.

\section{Introduction}

Plukenetia (Euphorbiaceae) is a pantropical genus of lianas and scrambling vines. Of the 20 known species, 12 are present in the Neotropics, 7 in Africa and Madagascar and 1 in Asia (Bussmann et al., 2009, 2013).

Plukenetia polyadenia ("amahua") grows in humid tropical rainforests, at altitudes from $0-1,000 \mathrm{~m}$. It's distributed in the Guianas, eastern Venezuela and the Amazon basin of Ecuador, Peru, Bolivia and Brazil (Gillespie and Armbruster, 1997). Its seed oil is used by native people of the Brazilian Amazon against arthritis and rheumatism, spreading it on the arms and legs to reduce the pain and inflammation, and presents antinociceptive activity without toxicity (Mota et al., 2015). Native communities in Loreto, Peru use its seeds as food.

Plukenetia volubilis ("sacha inchi") presents a high concentration of unsaturated fatty acids (omega 3,6 and 9), proteins and vitamins $\mathrm{A}$ and $\mathrm{E}$ in its seeds (Guillén et al., 2003) and the international market of its oil has been increasing significantly in recent years.

Wild species grow and develop in nature without human intervention because their genes confer characteristics of adaptation to adverse environmental conditions and pest tolerance (Sevilla and Holle, 2004). Nowadays there is interest in preserving all species of the genus Plukenetia as 
a source of genetic variability for use in breeding programs and Plukenetia polyadenia constitutes an important source of genes for genetic improvement of Plukenetia volubilis.

Vegetative propagation will allow us to conserve superior genotypes with $100 \%$ genetic identity. The success of vegetative propagation through rooting cuttings in sub-irrigation propagators depends of the minimization of water deficit, optimizing photosynthesis and the use of appropriate substrates and growth regulators that promote the formation and development of roots (Leakey et al., 1990). The application of growth regulators is important to increase the percentage of rooting, reduce root initiation time and improve the quality of the root system formed (Hartmann et al., 2002). The indole-3-butyric acid (IBA) is an effective auxin to promote rooting of cuttings in a large number of species. The advantages of the IBA are: it is not toxic in a wide range of concentrations, not easily degraded by light or microorganisms and has longer permanence at the application site exerting greater effect (Blazich, 1988).

Rooting cuttings of Plukenetia volubilis is possible using $9.84 \mathrm{mM}$ of IBA (Cachique et al., 2011) and the main goal of this study was to develop a method for vegetative propagation of Plukenetia polyadenia by rooting cuttings in sub-irrigation propagators.

\section{Material and Methods}

The genetic material of Plukenetia polyadenia was obtained from Pebas, Loreto, Peru. The experiment was laid out in a randomized complete block design with 12 treatments and 3 replications of 8 cuttings, in a $3 \times 4$ factorial arrangement. The factors were: 3 levels of leaf area $(25,50$ and $75 \%)$ and 3 concentrations of IBA $(9.84,19.68$ and $29.52 \mathrm{mM})$ and a control without IBA. Hormonal solutions were prepared dissolving chemically pure IBA in alcohol at $96 \%$ and the control treatment was water. Vigorous sprouts were selected and cuttings were prepared from middle portion of each sprout. Each cutting of $8 \mathrm{~cm}$ was placed in a water recipient to avoid dehydration during preparation. $10 \mu \mathrm{l}$ of solution of IBA was applied on the base of each cutting with a micropipette and then were placed in the substrate (medium texture sand) in the sub-irrigation propagator in holes of $2 \mathrm{~cm}$ depth at the distance of $10 \times 10 \mathrm{~cm}$.

For rooting cuttings we used sub-irrigation propagators, based on the Howland design (Leakey et al., 1990). Its structure was basically a wooden box covered with thick transparent plastic: the base of the propagator was filled with large and medium stones and gravel on which a sand layer of $5 \mathrm{~cm}$ with a medium texture was placed as rooting substrate. Water was added until the base of the substrate, so when we closed the propagator an indoor environment of high relative humidity was created and the substrate was wetted by capillary action. All materials used were previously washed and disinfected with sodium hypochlorite at $5.25 \%$. The propagator was protected with a mesh of $80 \%$ of shadow, in order to regulate the temperature and solar radiation. The average relative humidity was $88.5 \%$ and the average air temperature was $26.9^{\circ} \mathrm{C}$. For the control of fungal diseases, the cuttings were treated after 7 days with Carbendazima $\left(1.5 \mathrm{ml} \mathrm{L}^{-1}\right)$.

The evaluation was made 15 days after the cuttings were placed in the sub-irrigation propagator. Data were submitted to analysis of variance and means were compared by Tukey test at $5 \%$ probability. Before the analysis, percentage data were transformed using the formula $\arcsin \sqrt{x / 100}$ and the count data were transformed using $\sqrt{x+1}$ (Snedecor and Cochran, 1980).

\section{Results}

There was no significant interaction between levels of leaf area and concentrations of IBA on rooting variables studied, therefore studied factors act independently in the rooting process.

\subsection{Effects of different levels of leaf area on rooting of Plukenetia polyadenia cuttings}

The results indicate a significant effect of levels of leaf area in the rooting of Plukenetia polyadenia cuttings. We obtained the highest rooting and sprouting percentages with cuttings of $50 \%$ of leaf area. The number and length of roots were higher with 50 and $75 \%$ of leaf area. Cuttings with $25 \%$ of leaf area showed low percentage of rooting and poor root development (Table 1).

\subsection{Effects of different concentrations of IBA on rooting of Plukenetia polyadenia cuttings}

There was a significant effect of different concentrations of IBA in the rooting of Plukenetia polyadenia cuttings. The best root formation and higher sprouting percentage were obtained when we treated cuttings with $29.52 \mathrm{mM}$. The results of the rooting induction of cuttings decrease when we reduced the concentrations of IBA. The control treatment showed a low capacity to induce roots naturally (Table 2).

Table 1. Effects of different levels of leaf area on rooting of Plukenetia polyadenia cuttings.

\begin{tabular}{ccccc}
\hline $\begin{array}{c}\text { LEAF AREA } \\
\mathbf{( \% )}\end{array}$ & $\begin{array}{c}\text { ROOTING } \\
(\mathbf{\%})\end{array}$ & $\begin{array}{c}\text { ROOT } \\
\text { NUMBER }\end{array}$ & $\begin{array}{c}\text { ROT LENGTH } \\
(\mathbf{c m})\end{array}$ & $\begin{array}{c}\text { SPROUTING } \\
(\%)\end{array}$ \\
\hline $\mathbf{2 5}$ & $63.54 \mathrm{~b}$ & $4.69 \mathrm{~b}$ & $4.07 \mathrm{~b}$ & $61.46 \mathrm{~b}$ \\
$\mathbf{5 0}$ & $80.21 \mathrm{a}$ & $6.79 \mathrm{a}$ & $4.98 \mathrm{ab}$ & $83.33 \mathrm{a}$ \\
$\mathbf{7 5}$ & $68.75 \mathrm{~b}$ & $7.19 \mathrm{a}$ & $5.39 \mathrm{a}$ & $80.21 \mathrm{a}$ \\
\hline
\end{tabular}

Mean values in the same column followed by different letters indicate significant differences $(\mathrm{p}<0.05)$ between them. 
Table 2. Effects of different concentrations of IBA on rooting of Plukenetia polyadenia cuttings with $50 \%$ of leaf area.

\begin{tabular}{ccccc}
\hline $\begin{array}{c}\text { IBA } \\
\begin{array}{c}\text { CONCENTRATION } \\
(\mathbf{m M})\end{array}\end{array}$ & $\begin{array}{c}\text { ROOTING } \\
(\mathbf{\%})\end{array}$ & $\begin{array}{c}\text { ROOT } \\
\text { NUMBER }\end{array}$ & $\begin{array}{c}\text { ROOT LENGTH } \\
(\mathbf{c m})\end{array}$ & $\begin{array}{c}\text { SPROUTING } \\
(\mathbf{\%})\end{array}$ \\
\hline water & $26.39 \mathrm{c}$ & $1.06 \mathrm{~d}$ & $1.65 \mathrm{c}$ & $37.5 \mathrm{c}$ \\
$\mathbf{9 . 8 4}$ & $77.78 \mathrm{~b}$ & $5.06 \mathrm{c}$ & $5.39 \mathrm{~b}$ & $75 \mathrm{~b}$ \\
$\mathbf{1 9 . 6 8}$ & $86.11 \mathrm{ab}$ & $8.06 \mathrm{~b}$ & $5.62 \mathrm{ab}$ & $90.28 \mathrm{a}$ \\
$\mathbf{2 9 . 5 2}$ & $93.06 \mathrm{a}$ & $10.72 \mathrm{a}$ & $6.59 \mathrm{a}$ & $97.28 \mathrm{a}$ \\
\hline
\end{tabular}

Mean values in the same column followed by different letters indicate significant differences $(\mathrm{p}<0.05)$ between them.

\section{Discussion}

\subsection{Effects of different levels of leaf area on rooting of Plukenetia polyadenia cuttings}

Low temperatures are important because evaporation rates are lower and humidity is temperature dependent, so low temperatures help avoid water stress by maintaining high relative humidity (Leakey and Mesén, 1991). Experiences with other tropical species show that the optimum temperature of the air that favors the rooting is between $20-25^{\circ} \mathrm{C}$, although temperatures until $30{ }^{\circ} \mathrm{C}$ are acceptable as long as the relative humidity is less than $95 \%$ (Ruiz-Solsol and Mesén, 2010). The values obtained in this study are within these ranges and contributed to success.

The beginning of root primordia formation is hormonally controlled and the reserves present in the cuttings and photo assimilates produced in the leaves influence its development. Previous studies indicate that there is an optimum leaf area for rooting (Leakey and Coutts, 1989) and varies among species. In Plukenetia polyadenia the best result was obtained with $50 \%$ of leaf area (Figure 1) due to higher photosynthetic production of leaves (Cachique et al., 2011).

The leaves influence the rooting of cuttings (Hartmann et al., 2002) because they are a source of photoassimilates, auxins and other vital substances for rooting, however, the leaves provide a large surface from which the cuttings lose water through transpiration (Mesén, 1998). Plukenetia polyadenia cuttings with $50 \%$ of leaf area achieve the best balance between the disadvantages of transpiration and advantages of photosynthesis. Similarly, the use of $50 \%$ of leaf area allowed high percentages of rooting in cuttings of Plukenetia volubilis (Cachique et al., 2011). The use of cuttings with $75 \%$ of leaf area promotes water loss and decreases the rooting percentage (Table 1). It is important to maintain a high water potential in leaves to decrease oxidase activity in photosynthesis and increase the activity of endogenous auxins (Loach, 1977).

The procedure of leaf size reduction is quite usual in order to reduce water loss. However, retention of the maximum leaf area may produce a stronger root system in a shorter period, because root initiation and growth require adequate oxygen supply (Bona and Biasi, 2010). The number and length of roots increase when using cuttings with greater leaf area (Table 1). The same relation was observed in Scleroxylon tryplochiton cuttings, wherein fewer roots were obtained with $10 \%$ of leaf area compared

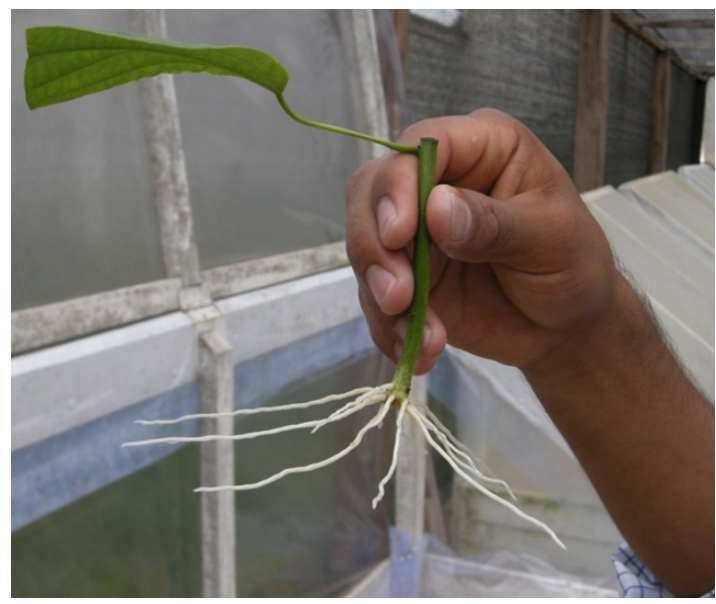

Figure 1. Rooted cutting of Plukenetia polyadenia after 15 days of treatment with $29.52 \mathrm{mM}$ of IBA.

with the results obtained with $50 \%$ of leaf area; this was attributed to increased production of soluble carbohydrates (Leakey and Coutts, 1989). Cuttings with 25\% of leaf area present poor root development, being necessary to use cuttings with at least $50 \%$ of leaf area in rooting of Plukenetia polyadenia.

Compounds synthesized in the leaves through photosynthesis and carbohydrate reserves present in the cuttings influenced the shoot development. Cuttings of Plukenetia polyadenia with 50 and $75 \%$ of leaf areas showed higher sprouting percentage, with similar results obtained in rooting cuttings of Plukenetia volubilis (RuizSolsol and Mesén, 2010).

\subsection{Effects of different concentrations of IBA on rooting of Plukenetia polyadenia cuttings}

The purpose of treating cuttings with growth regulators is to increase the percentage of rooting, reduce root initiation time and improve the quality of the formed root system (Cachique et al., 2011), being IBA the most effective auxin to induce rooting of cuttings in most species. The advantages of IBA are: it is not toxic in a wide range of concentrations, not easily degraded and has longer permanence in the application site than other auxins (Blazich, 1988). The cuttings of Plukenetia polyadenia that were not treated with IBA presented $26.39 \%$ of rooting, showing that the level of endogenous auxin allows a 
low formation of adventitious roots, being necessary the application of IBA. The rooting percentage of Plukenetia polyadenia increases when using higher concentrations of IBA, with best results when using $29.52 \mathrm{mM}$ (Table 2). A similar result was observed in Plukenetia volubilis (Cachique et al., 2011). The positive effects of auxins on rooting have been associated with its effects on cell division, increased transport of carbohydrates and other foliar cofactors to application sites and stimulation of DNA synthesis in cells treated (Ruiz-Solsol and Mesén, 2010).

The cuttings usually respond to concentrations of auxin in a typical way, showing a progressive increase in the number and quality of roots formed with each increase in concentration auxin reaching a peak, from which a descent begins in response due to toxicity (Mesén, 1998). The number and length of roots in Plukenetia polyadenia is higher with the increasing concentrations of IBA and the use of $29.52 \mathrm{mM}$ allowed to obtain 10.72 roots of $6.59 \mathrm{~cm}$. Root formation was influenced by the ability of cuttings to provide carbohydrates to the area where the roots emerge. In Plukenetia volubilis was observed that the capacity of rooting cuttings increases with higher concentrations of IBA, until reaching an optimum of $9.84 \mathrm{mM}$. Any increase of IBA acts by decreasing the percentage of rooting (Cachique et al., 2011; Ruiz-Solsol and Mesén, 2010). Plukenetia polyadenia cuttings that were not treated with IBA had 1.06 roots with $1.65 \mathrm{~cm}$ indicating a low capacity to induce roots naturally.

Plukenetia polyadenia cuttings that were not treated with IBA developed the sprouts before the roots; this behavior has also been observed in Plukenetia volubilis (Ruiz-Solsol and Mesén, 2010) and other tropical species. Sprouting percentage increases when using higher concentrations of IBA, with best results when using $29.52 \mathrm{mM}$ in Plukenetia polyadenia cuttings (Table 2). Sprouting is influenced by the amount of IBA applied, the amount of reserves present in the cuttings and photoassimilates produced in the leaves (Ruiz-Solsol and Mesén, 2010).

\section{Conclusion}

Vegetative propagation of Plukenetia polyadenia through rooting of cuttings in sub-irrigation propagators was possible using medium texture sand as substrate, with the application of $29.52 \mathrm{mM}$ of IBA as hormonal inductor and cuttings with $50 \%$ of leaf area. This method will be used as a tool to conserve and propagate germplasm in breeding programs.

\section{Acknowledgements}

The authors thank Fund for Innovation, Science and Technology - FINCyT, Peru, for financial support to develop this research.

\section{References}

BLAZICH, F.A., 1988. Chemicals and formulations used to promote adventitious rooting. In: DAVIS, T.D., HAISSIG, B.E. and SANKHLA, N., eds. Adventitious root formation in cuttings. Portland: Dioscorides Press, pp. 132-149.
BONA, C.M. and BIASI, L.A., 2010. Influence of leaf retention on cutting propagation of Lavandula dentata L. Revista Ceres, vol. 57, no. 4, pp. 526-529. http://dx.doi.org/10.1590/S0034737 X2010000400014.

BUSSMANN, R., PANIAGUA ZAMBRANA, N. and TÉLLEZ, C., 2013. Plukenetia carolis-vegae (Euphorbiaceae):a new useful species from Northern Peru. Economic Botany, vol. 67, no. 4, pp. 387-392. http://dx.doi.org/10.1007/s12231-013-9247-2.

BUSSMANN, R., TELLEZ, C. and GLENN, A., 2009. Plukenetia huayllabambana sp. nov. (Euphorbiaceae) from the upper Amazon of Perú. Nordic Journal of Botany, vol. 27, no. 4, pp. 313-315. http://dx.doi.org/10.1111/j.1756-1051.2009.00460.x.

CACHIQUE, D., RODRÍGUEZ, A., RUIZ-SOLSOL, H., VALLEJOS, G. and SOLIS, R., 2011. Propagación vegetativa del sacha inchi (Plukenetia volubilis L.) mediante enraizamiento de estacas juveniles en cámaras de subirrigación en la Amazonía Peruana. Folia Amazónica, vol. 20, no. 1-2, pp. 95-100.

GILLESPIE, L.J. and ARMBRUSTER, W.S., 1997. A Contribution to the Guianan Flora: Dalechampia, Haematostemon, Omphalea, Pera, Plukenetia and Tragia (Euphorbiaceae) with Notes on Subfamily Acalyphoideae. Washington: Smithsonian Institution Press. 48 p. http://dx.doi.org/10.5962/bhl.title.103726.

GUILlÉN, M.D., RUIZ, A., CABO, N., CHIRINOS, R. and PASCUAL, G., 2003. Characterization of sacha inchi (Plukenetia volubilis L.) oil by FTIR spectroscopy and H NMR: comparison with linseed oil. Journal of the American Oil Chemists 'Society, vol. 80 , no. 8 , pp. $755-762$. http://dx.doi.org/10.1007/s11746003-0768-z.

HARTMANN, H.T., KESTER, D.E., DAVIES, F.T. and GENEVE, R.L., 2002. Plant propagation: principles and practices. 7 th ed. New Jersey: Prentice Hall. 880 p.

LEAKEY, B., MESÉN, F., TCHOUNDJEU, Z., LONGMAN, A., DICK, J., NEWTON, A., MARTIN, A., GRACE, J., MUNRO, C. and MUTHOKA, N., 1990. Low technology techniques for the vegetative propagation of tropical trees. Commonwealth Forestry Review, vol. 69, no. 3, pp. 247-257.

LEAKEY, R.R.B. and COUTTS, M.P., 1989. The dynamics of rooting in Triplochiton scleroxylon K. Schum. cuttings: their relation to leaf areas, node position, dry weight accumulation, leaf water potential and carbohydrate composition. Tree Physiology, vol. 5, no. 1, pp. 135-146. http://dx.doi.org/10.1093/treephys/5.1.135. PMid:14973005.

LEAKEY, R.R.B. and MESÉN, F., 1991. Métodos de propagación vegetativa en árboles tropicales: enraizamiento de estacas suculentas. In: CORNELIUS, J.P., MESÉN F. and COREA, E., eds. Manual sobre mejoramiento genético forestal con referencia especial a América Central. Turrialba: CATIE, pp. 135-153.

LOACH, K., 1977. Leaf water potential and the rooting of cuttings under mist and polythene. Physiologia Plantarum, vol. 40, no. 3, pp. 191-197. http://dx.doi.org/10.1111/j.1399-3054.1977.tb04056.x.

MESÉN, F., 1998. Enraizamiento de estacas juveniles de especies forestales: uso de propagadores de subirrigación. Turrialba: CATIE. 36 p. Manual Técnico, no. 30.

MOTA, A.S., LIMA, A.B., ALBUQUERQUE, T.L., SILVEIRA, T.S., NASCIMENTO, J.L., SILVA, J.K., RIBEIRO, A.F., MAIA, J.G. and BASTOS, G.N., 2015. Antinociceptive activity and toxicity evaluation of the fatty oil from Plukenetia polyadenia Mull. Arg. (Euphorbiaceae). Molecules, vol. 20, no. 5, pp. 7925-7939. http://dx.doi.org/10.3390/molecules20057925. PMid:25942373. 
Solis, R. et al.

RUIZ-SOLSOL, H. and MESÉN, F., 2010. Efecto del ácido indolbutírico y tipo de estaquilla en el enraizamiento de sacha inchi (Plukenetia volubilis L.). Agronomía Costarricense, vol. 34, no. 2, pp. 259-267.
SEVILLA, R. and HOLLE, M., 2004. Recursos genéticos vegetales. Lima: Ediciones Torre Azul. 445 p.

SNEDECOR, W. and COCHRAN, G., 1980. Statistical methods. 7th ed. Iowa: State University Press. 507 p. 